\title{
Fluctuating Hemiparesis as a Result of Traumatic Brain Injury-associated Hyponatremia
}

Sir,

Hyponatremia causing a fluctuating and transient motor deficit is an extremely rare phenomenon in clinical medicine and has very rarely been reported in literature. $^{[1,2]}$ Syndrome of inappropriate antidiuretic hormone secretion has been reported in literature in about $4.6 \%$ of head injuries, being most prevalent in the moderate head injury group. ${ }^{[1]}$ Hyponatremia, in a traumatic brain injury, is hypothesized to occur secondary to a posterior pituitary dysfunction and is usually transient. ${ }^{[1]}$

A 25-year-old male presented to our emergency room services with a history of hemiplegia of 1-day duration. He had a preceding history of a head injury $48 \mathrm{~h}$ prior and had been admitted to another hospital. On examination, he was conscious, alert, and oriented. He had a right hemiplegia but no other deficits. His motor power had been normal for over $24 \mathrm{~h}$ after the injury. His computed tomography (CT) scan brain revealed perisylvian frontal and temporal contusions [Figure 1]. $\mathrm{He}$ was monitored in the Intensive Care Unit and a battery of routine tests was done. The laboratory results revealed serum sodium of $108 \mathrm{mg} / \mathrm{dl}$ (which was reconfirmed twice). Other causes for the hemiplegia were ruled out: a repeat CT scan of the brain did not reveal any progression of the contusions or a new middle cerebral artery infarct and his blood sugar levels and electroencephalography were normal. His hyponatremia was found to be hypoosmolar (serum osmolality of $260 \mathrm{mg} / \mathrm{dl}$ and urine osmolality of $150 \mathrm{mOSm} / \mathrm{kg}$ ), and he was treated with hyperosmolar saline and later tolvaptan. An interesting phenomenon was recorded over the next 4 days with the level of fluctuating hemiparesis corresponding with the serum sodium levels as depicted in Figure 2. The hemiparesis completely abated with normalization of the serum sodium levels. No cause for chronic hyponatremia was found. At review, a month later, the patient had no residual deficit and his serum sodium level was $136 \mathrm{mg} / \mathrm{dl}$.

One of the common causes of hyponatremia is iatrogenic ( $3 \%$ prevalence in general hospitals) and one of the common causes cited is intravenous fluids. ${ }^{[2]}$ Since

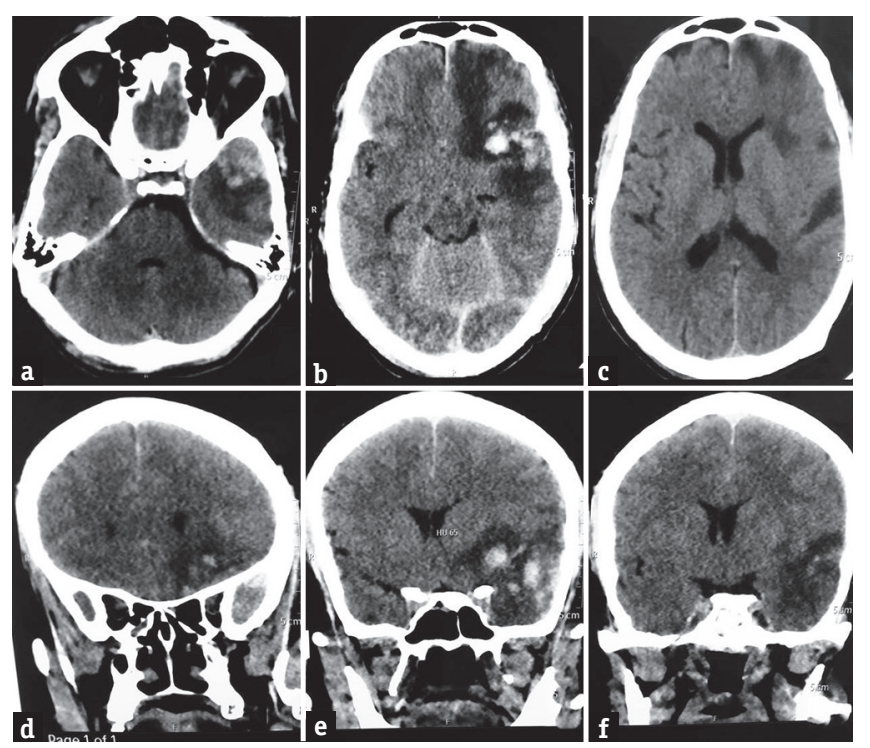

Figure 1: Axial (a-c) and coronal (d-f) computed tomography scan images of the brain revealing the left frontotemporal contusions with perilesional edema. Some mass effect is demonstrable but no midline shift 


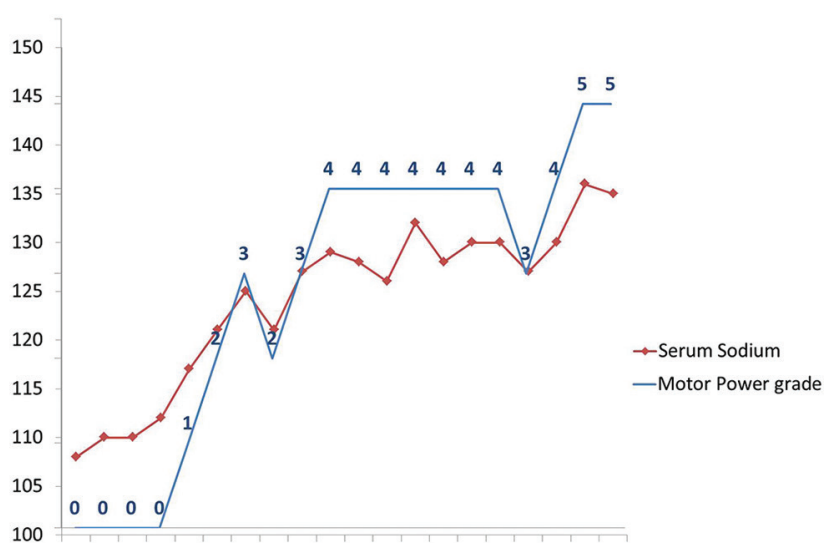

Figure 2: The correlation between the serum sodium levels and the fluctuating motor paresis

this patient was admitted to another hospital for $48 \mathrm{~h}$, it is hard to determine if the cause of the hyponatremia was iatrogenic or trauma per se. Hyponatremic patients become symptomatic once the serum sodium levels dip below 125. ${ }^{[2]}$ These symptoms range from mild confusion to coma and may depict mono- or hemiparesis which may be related to earlier structural lesions. ${ }^{[2]}$ The presentation and clinical course of the current patient was clinically confusing and could easily have been overlooked.

In conclusion, the authors would like stress that although extremely rare, hyponatremia causing hemiparesis should be considered in the differential diagnosis of unexplained and fluctuating hemiparesis.

\section{Declaration of patient consent}

The authors certify that they have obtained all appropriate patient consent forms. In the form the patient(s) has/have given his/her/their consent for his/ her/their images and other clinical information to be reported in the journal. The patients understand that their names and initials will not be published and due efforts will be made to conceal their identity, but anonymity cannot be guaranteed.

\section{Financial support and sponsorship \\ Nil.}

\section{Conflicts of interest}

There are no conflicts of interest.

\section{Ravi Dadlani ${ }^{1,2}$, Rahul Agrawal}

${ }^{1}$ Department of Neurosurgery, Zulekha Hospital, Sharjah, UAE, Departments of ${ }^{2}$ Neurosurgery and ${ }^{3}$ General Medicine, MaxCure Hospitals, Hyderabad, Telangana, India

Address for correspondence: Dr. Ravi Dadlani, Department of Neurosurgery, Zulekha Hospital, P. O. Box: 457, Sharjah, UAE. E-mail: ravi.dadlani@gmail.com

\section{REFERENCES}

1. Zasler N, Katz MD, Zafonte DO. Brain injury medicine principles and practice. In: Kirby FD, Creasey L, Abou-Assi SG, editors. Medical Management Issues: Gastrointestinal and Nutritional Issues. New York: Demos Publishing; 2007. p. 662.

2. Angel MJ, Bryan Young G. Metabolic encephalopathies. Neurol Clin 2011;29:837-82.

This is an open access journal, and articles are distributed under the terms of the Creative Commons Attribution-NonCommercial-ShareAlike 4.0 License, which allows others to remix, tweak, and build upon the work non-commercially, as long as appropriate credit is given and the new creations are licensed under the identical terms.

\begin{tabular}{|l|l|}
\hline \multicolumn{2}{|c|}{ Access this article online } \\
\hline Quick Response Code: & Website: \\
\hline
\end{tabular}

How to cite this article: Dadlani R, Agrawal R. Fluctuating hemiparesis as a result of traumatic brain injury-associated hyponatremia. J Neurosci Rural Pract 2018;9:445-6.

c 2018 Journal of Neurosciences in Rural Practice | Published by Wolters Kluwer - Medknow 